LINGUA, Vol. 16, No. 2, September 2019

p ISSN: 1979 9411; e ISSN: 2442 238X

Http://lingua.soloclcs.org; Email: presslingua@gmail.com

Center of Language and Cultural Studies, Surakarta, Indonesia

Nasip, Abdul; Mahyuni \& Nuriadi. 2019. Nilai Pendidikan, Sosial, Kultural dan Spiritual dalam Wasiat Renungan Masa, Karya TGKH. Zainuddin Abdul Madjid: Tinjauan Hermeneutika.

Lingua (2019), 16(2): 271-284. Http://doi.org/10.30957/lingua.v16i2.270.

\title{
Nilai Pendidikan, Sosial, Kultural, dan Spiritual dalam Wasiat Renungan Masa Karya Tgkh. Zainuddin Abdul Madjid: Tinjauan Hermeneutika
}

\author{
Abdul Nasip, Mahyuni \& Nuriadi \\ Magister Pendidikan Bahasa Indonesia Universitas Mataram \\ Jalan Majapahit No. 62 Mataram, Nusa Tenggara Barat \\ Corresponding Email: abdulnasipnw1988@gmail.com \\ yonmahy@yahoo.com \& nuriadi@unram.ac.id
}

\begin{abstract}
The Testament of Devotional Period is one type of literary work in the form of poetry by TGKH. Zainuddin bin Abdul Madjid, the founder of Nahdlatul Wathan (NW) organization in Lombok. The purpose of this study is to explore character education values in the testament using hermeneutic theory of HansGeorge Gadamer. Primary data of this study were values in the text of testatment and the secondary data were results of review of literature, and results of interview. Results show values contained in the testament include: character education, social, cultural, and spiritual, with character education as the dominant value. Factors that cause the dominance of the value of character education in the testament include: effort to maintain the existence of NW, fostering the attitude of sami'na waata'na to NW alumni, a tool to suggest fighting spirit for NW, heirs of the Prophets, and fostering fanaticism towards NW.
\end{abstract}

Keywords:testament, character education, social, cultural, spiritual

\section{PENDAHULUAN}

Karya sastra merupakan hasil pengungkapan jiwa pengarang yang dipengaruhi oleh kehidupan berupa peristiwa dan pengalaman hidup yang telah dilaluinya. Hal tersebut karena pengarang merupakan anggota masyarakat yang hidup dan berhubungan dengan orang-orang di sekitarnya, sehingga dalam proses penciptaan sebuah karya sastra, lingkungan akan selalu memengaruhi seorang pengarang. Oleh karena itu, dapat dikatakan bahwa karya sastra merupakan cerminan dari kondisi masyarakat tempat pengarang tersebut menjalani kehidupannya. Adapun pencerminan yang dimaksud dalam suatu karya sastra terdapat dalam aspek nilai-nilai.

Wasiat Renungan Masa terdiri atas empat 4 macam Wasiat yang ditulis dalam waktu yang berbeda-beda, yaitu: Wasiat pada 23 September 1976, berisi tentang wasiat yang ditujukan kepada anak dan murid-muridnya. hal ini disebabkan karena TGKH. Zainuddin Abdul Madjid melihat ada penyelewengan abituren (murid) yang dikirim melanjutkan pendidikan ke pulau Jawa. Namun setelah kembali dari Jawa. bukannya 
LINGUA, Vol. 16, No. 2, September 2019

p ISSN: 1979 9411; e ISSN: 2442 238X

Http://lingua.soloclcs.org; Email: presslingua@gmail.com

Center of Language and Cultural Studies, Surakarta, Indonesia

Nasip, Abdul; Mahyuni \& Nuriadi. 2019. Nilai Pendidikan, Sosial, Kultural dan Spiritual dalam Wasiat Renungan Masa, Karya TGKH. Zainuddin Abdul Madjid: Tinjauan Hermeneutika.

Lingua (2019), 16(2): 271-284. Http://doi.org/10.30957/lingua.v16i2.270.

membantu perjuangan beliau, tapi malah melawan bahkan merong-rong perjuangan beliau. Itulah sebabnya TGKH. Zainuddin Abdul Madjid dalam wasiatnya mengatakan sebaik-baikmu padaku adalah orang yang paling banyak memberikan manfaat kepada Nahdlatul Wathan (NW) dan sejahat-jahatmu padaku ialah yang paling banyak merusak perjuangan NW.

Wasiat pada 7 Oktober 1981, sebanyak 233 Wasiat. Wasiat tersebut ditulis oleh TGKH. Zainuddin Abdul Madjid setelah melihat situasi dunia Islam terus menerus dikepung dan dirong-rong oleh lawan dan atek-antek mereka. Sayang umat Islam sendiri kebanyakan lengah dan tertidur nyenyak tidak mengetahui tugasnya sendiri.Selanjutnya wasiat yang disampaikan pada 7 Oktober 1981 ditulis oleh TGKH. Zainuddin Abdul Madjid untuk menjaga kemungkinan umat Islam salah I'tiqad atau salah jalan bagi umat Islam sendiri dalam menegakkan kesucian dan kemurnian syariat Islam (iman dan takwa) terutama bagi generasi penerus bangsa.

Adapun Wasiat pada 1 Maret 1970, berisi 112 bait. Wasiat tersebut disampaikan dihadapan para mahasiswa/i (Tullab Ma'had Darul Quran wal-Hadis al-Majidiyyah Asyafi'iyyah Nahdlatul Wathan) guru-guru dan seruluh pelajar NWDI dan NBDI. Wasiat ini ditulis oleh TGKH. Zainuddin Abdul Madjid dikarenakan beliau melihat di dalam tubuh organisasi NW sepertinya akan terjadi perpecahan dan akan terjadi fitnah. Hal ini terbukti ketika muktamar ke-10 di Praya, yang mana ketika itu Ketua umum Pengurus Besar NW terpilih adalah Ummi Hajjah Siti Raihanun, namun pihak yang kalah dalam muktamar tersebut tidak terima lalu memisahkan diri, kemudian membuat pengurus baru.

Sementara itu, wasiat pada 28 September 1970 berisi 88 adalah wasiat terakhir yang ditulis oleh TGKH. Zainuddin Abdul Madjid sebagai tambahan dari wasiat sebelumnya yang dikeluarkan pada 1 Maret 1970. Wasiat ini diamanatkan kepada anak dan keturunan beliau sebagai bekal dalam berjuang dan mempertahankan eksistensi organisasi NW.

Selanjutnya, WRM merupakan pengalaman pengarang selama hidupnya yang lahir dari proses panjang. Mulai semenjak kepulangan beliau dari tanah suci Makkah Al-Mukarramah, sampai akhir hayatnya. Sehingga dalam WRM tersebut sepertinya terdapat banyak nilai-nilai yang terkandung di dalamnya yang bisa dijadikan sebuah rujukan dan pedoman hidup bagi semua orang dalam bermasyarakat, pendidikan, budaya, sosial, bahkan dalam hal yang berhubungan dengan sebuah kepercayaan kepada Tuhan.

Berdasarkan uraian di atas, maka kajian terhadap Wasiat Renungan Masa dianggap perlu untuk dilakukan kembali. Saat ini masih sedikit sekali yang meneliti tentang WRM sehingga penelitian yang berjudul "Nilai Pendidikan, Sosial, Kultural, dan Spiritual dalam Wasiat Renungan Masa Karya TGKH. Zainuddin Abdul Madjid: Tinjauan Hermeneutika" ini dirasa perlu untuk dilakukan kembali. Adapun teori dasar yang digunakan untuk mengkaji hal tersebut ialah hermeneutika Gadamer.

Hermeneutika Gadamer merupakan metode tafsir dalam aliran filsafat yang memandang makna teks bukan suatu yang ada di teks itu sendiri, tapi makna terus selalu ditelusuri melalui orang lain pasangan komunikasinya bersifat relatif bagi penafsirnya 
LINGUA, Vol. 16, No. 2, September 2019

p ISSN: 1979 9411; e ISSN: 2442 238X

Http://lingua.soloclcs.org; Email: presslingua@gmail.com

Center of Language and Cultural Studies, Surakarta, Indonesia

Nasip, Abdul; Mahyuni \& Nuriadi. 2019. Nilai Pendidikan, Sosial, Kultural dan Spiritual dalam Wasiat Renungan Masa, Karya TGKH. Zainuddin Abdul Madjid: Tinjauan Hermeneutika.

Lingua (2019), 16(2): 271-284. Http://doi.org/10.30957/lingua.v16i2.270.

(Ricoeur, 2014:53). Lebih lanjut dikatakan makna yang harus dicari, didekonstruksikan, dan direkonstruksi oleh penafsir sesuai dengan konteksnya, dimana, dan kapan penafsiran itu dibuat, sehingga makna teks tidak pernah baku melainkan selalu mengalami perubahan. Jadi makna teks selalu dengan konteks. Penafsir dan teks selalu terikat dalam tradisi masing-masing. Penafsir ketika penafsiran harus selalu mempunyai pra paham terhadap teks yang hendak ditafsirkan (Susanto, 2012:204). Hal yang menunjukkan bahwa Gadamer beranggapan bahwa pembaca paham masa lalu teks, tapi dari sudut dan situasi dan pandangan pembaca.

Gadamer (dalam Ricoeur, 2014:171) menegaskan bahwa setiap terjemahan pada saat yang sama adalah penerjemahan biasa, bahkan penerjemahan sesungguhnya, penuntasn interpretasi, sebab ketika penerjemahan memberikan kata-kata bagi interpretasinya berarti memberi tubuh pada interpretasi. Pemahaman sendiri bagi Gadamer bukanlah merupakan proses subjektif manusia yang dihadapkan pada satu objek, begitu juga pemahaman bukan suatu metode objektivitas. Lebih dari itu, pemahaman menurut Gadamer merupakan modus existendi manusia, yakni peristiwa pemahaman senantiasa merupakan peristiwa historikal, dialektik dan kebahasaan.

Adapun rumusan masalah dalam kajian ini adalah: 1) Nilai apa saja yang terkandung dalam Wasiat Renungan Masa?; 2) Nilai apa saja yang dominan dalam Wasiat Renungan Masa?; dan 3) Faktor apa saja yang menyebabkan nilai tersebut dominan dalam Wasiat Renungan Masa?.

\section{METODE}

Penelitian bersifat deskriptif dengan jenis penelitian kualitatif. Penelitian kualitatif meneliti pada kondisi objek yang alamiah dan deskriptif (Sugiyono, 2016:15). Disebut penelitian kualitatif karena berusaha mengumpulkan data, menganalisis data, dan membuat interpretasi tentang isi teks Wasiat Renungan Masa secara kualitatif. Yang menjadi bahan kajian yaitu nilai pendidikan, nilai sosial, nilai kultural, dan nilai spiritual pada teks Wasiat Renungan Masa Karya TGKH. Zainuddin Abdul Madjid.

Data penelitian meliputi data primer dan data sekunder (Pradopo, 2013:49). Data primer penelitian ini ialah fenomena kebahasaan yang terdapat di dalam teks yang mengandung nilai pendidikan, sosial, kultural, dan spiritual dalam Wasiat Renungan Masa karya TGKH. Zainuddin Abdul Madjid baik yang berbahasa daerah Sasak maupun berbahasa Indonesia. Naskah berjumlah 158 halaman terbagi menjadi tiga bagian, yaitu bagian pertama 233 bait, bagian kedua sebanyak 112 bait, dan bagian ketiga sebanyak 88 bait.

Data sekunder adalah data yang diperoleh dari data pendukung untuk memperjelas data primer berupa data kepustakaan yang berkaitan erat dengan objek penelitian. Data sekunder diperoleh dari sumber-sumber buku, artikel, majalah, wawancara serta data-data lain yang relevan dengan penelitian ini. Kemudian metode yang digunakan dalam menyajikan hasil analisis data penelitian yang akan dilakukan ini ialah metode informal (Mahsun, 2011:202). Hasil analisis data penelitian disajikan secara menggunakan kata-kata dan kalimat naratif. 


\section{HASIL DAN PEMBAHASAN}

\subsection{Nilai Pendidikan Karakter}

Pendidikan menurut John Dewe (dalam, Hasbullah 26:2001) adalah proses pembentukan kecakapan-kecakapan fundamental secara intlektual dan emosional kearah alam dan manusia. Sedangkan karakter menurut Kemendiknas (dalam, Agus Wibowo 28:2010) adalah watak, tabiat, akhlak, atau keperibadian seseorang yang terbentuk dari hasil internalisasi yang diyakini dan digunakan sebagai landasan cara pandang, berfikir, dan bertindak. Nilai pendidikan karakter adalah suatu sistem penanaman nilai kepada peserta didik yang mengandung komponen pengetahuan, kesadaran individu, tekad serta adanya kemauan yang dilakukan dalam kehidupan sehari-hari.

Nilai pendidikan karakter yang terdapat dalam Wasiat Renungan Masa karya TGKH. Zainuddin Abdul Madjid ada 12 nilai, yaitu:

- kejujuran

- amanah

- ikhlas

- kebaktian dan kesetiaan

- rasa ingin tahu

- ketekunan dan kesabaran

- hormat

- kebaikan

- disiplin

- keteladanan

- kerja keras

- ketaatan

\subsubsection{Nilai Sosial}

Menurut Febri (10:2018) nilai sosial adalah nilai yang dianut oleh suatu masyarakat, mengenai apa yang dianggap baik dan apa yang dianggap buruk oleh masyarakat. Sesuatu dikatakan baik atau buruk, pantas atau tidak pantas harus melalui proses menimbang. Hal ini, tentu sangat dipengaruhi oleh kebudayaan yang dianut masyarakat. Sedangkan menurut Bertrand (dalam, Febri 10, 2018) nilai sosial adalah suatu kesadaran yang disertai emosi yang relative lama hilangnya terhadap suatu objek, gagasan, atau orang. Menurut Williams (dalam, Febri10:2018) nilai sosial adalah hal yang menyangkut kesejahteraan bersama melalui konsensus yang efektif di antara mereka, sehingga nilai-nilai sosial dijunjung tinggi oleh banyak orang.

Nilai sosial Wasiat Renungan Masa karya TGKH. Zainuddin bin Abdul Madjid mencakup:

- persatuan

- pengabdian

- tolong-menolong

- kebersamaan 


\subsubsection{Nilai Kultural}

Dalam Kamus Besar Bahasa Indonesia (KBBI), nilai budaya konsep abstrak mengenai masalah dasar yang sangat penting dan bernilai dalam kehidupan manusia. Sedangkan menurut Daeng (dalam, Wildan 2005:16) mengatakan bahwa nilai budaya adalah sejumlah pandangan atau pemikiran terkait hal-hal yang paling berharga dan bernilai dalam hidup manusia. Dalam Wasiat Renungan Masa karya TGKH. Zainuddin bin Abdul Madjid terdapat 4 nilai budaya yaitu:

- kepercayaan

- ziarah

- nilai bai'at

- nikah masal

\subsubsection{Nilai Spiritual}

Nilai spiritual adalah sesuatu nilai yang berhubungan dengan sesuatu nilai yang sakral dan agung. Nilai spiritual merupakan nilai tertinggi dan bersifat mutlak karena bersumber kepada Tuhan Yang Maha Esa. Dalam Wasiat Renungan Masa karya TGKH. Zainuddin bin Abdul Madjid terdapat 4 nilai spiritual yaitu:

- iman dan takwa

- tauhid

- tawakkal

- bersyukur

- taat menjalankan perintah agama

\subsection{Nilai-Nilai Dominan dalam Teks}

Nilai-nilai yang dominant mencakup pendidikan karakter sosial, kultural, dan spiritual dan frekuensi dalam teks disajikan dalam tabel 1.

Tabel 1. Frekuwnsi Nilai Dominan dalam Teks

\begin{tabular}{|c|c|c|c|}
\hline No. & \multicolumn{2}{|c|}{ Macam-macam Nilai dalam Wasiat Renungan Masa } & Jumlah \\
\hline \multirow[t]{13}{*}{1.} & \multirow{13}{*}{$\begin{array}{l}\text { Nilai Pendidikan } \\
\text { Karakter }\end{array}$} & Nilai Kejujuran & 7 \\
\hline & & Nilai Amanah & 18 \\
\hline & & Nilai Ikhlas & 8 \\
\hline & & Nilai Kebaktian & 9 \\
\hline & & Nilai Rasa Ingin Tahu & 8 \\
\hline & & Nilai Ketekunan dan Kesabaran & 6 \\
\hline & & Nilai Hormat & 3 \\
\hline & & Nilai Kebaikan & 2 \\
\hline & & Nilai Disiplin & 4 \\
\hline & & Nilai Keteladanan & 7 \\
\hline & & Nilai Kerja Keras & 5 \\
\hline & & Nilai Ketaatan & 13 \\
\hline & & Jumlah & 90 \\
\hline \multirow[t]{3}{*}{2.} & \multirow[t]{3}{*}{ Nilai Sosial } & Nilai Persatuan & 12 \\
\hline & & Nilai Pengabdian & 7 \\
\hline & & Nilai Kasih Sayang & 2 \\
\hline
\end{tabular}


LINGUA, Vol. 16, No. 2, September 2019

p ISSN: 1979 9411; e ISSN: 2442 238X

Http://lingua.soloclcs.org; Email: presslingua@gmail.com

Center of Language and Cultural Studies, Surakarta, Indonesia

Nasip, Abdul; Mahyuni \& Nuriadi. 2019. Nilai Pendidikan, Sosial, Kultural dan Spiritual dalam Wasiat Renungan Masa, Karya TGKH. Zainuddin Abdul Madjid: Tinjauan Hermeneutika.

Lingua (2019), 16(2): 271-284. Http://doi.org/10.30957/lingua.v16i2.270.

\begin{tabular}{|c|c|c|c|}
\hline & & Nilai Tolong-menolong & 13 \\
\hline & & Nilai Kebersamaan & 11 \\
\hline & & Jumlah & 45 \\
\hline \multirow[t]{7}{*}{3.} & \multirow[t]{7}{*}{ Nilai Kultural } & Sistem Kepercayaan & 2 \\
\hline & & Ziarah & 10 \\
\hline & & Bai'at & 13 \\
\hline & & Berdoa (Berhizib) & 4 \\
\hline & & Nikah Masal & 6 \\
\hline & & Situs-Situs Bersejarah & 5 \\
\hline & & Jumlah & 40 \\
\hline \multirow[t]{6}{*}{4.} & \multirow[t]{6}{*}{ Nilai Spiritual } & Nilai Iman dan Takwa & 20 \\
\hline & & Nilai Tauhid & 3 \\
\hline & & Nilai Tawakkal & 4 \\
\hline & & Nilai Bersyukur & 4 \\
\hline & & Nilai Taat Menjalankan Perintah Agama & 4 \\
\hline & & Jumlah & 35 \\
\hline
\end{tabular}

Berdasarkan data pada tabel di atas, diketahui bahwa nilai yang dominan dalam Wasiat Renungan Masa karya TGKH. Zainuddin bin Abdul Madjid adalah nilai pendidikan karakter.

\subsection{Faktor-faktor yang menyebabkan terjadinya dominasi salah satu nilai}

Dalam Wasiat Renungan Masa Karya TGKH. Zainuddin Bin Abdul Madjid terdapat beberapa faktor yang mempengaruhi dominasi nilai pendidikan karakter, yaitu:

\subsubsection{Upaya menjaga eksistensi Organisasi NW}

Organisasi Nahdlatul Wathan yang didirikan oleh TGKH. Zainuddin bin Abdul Madjid sebagai sebuah organisasi kemasyarakatan yang berperan aktif dibidang pendidikan, sosial dan dakwah, oleh pendirinya sejak didirikan sampai saat ini berusaha dikembangkan dan disebarluaskan, tidak hanya pada lingkup alumni, abituren, dan pecinta saja. Namun kearah yang lebih luas yakni kepada masyarakat secara umum. Bahkan saat ini, organisasi NW tidak hanya berkembang disekitar Nusa Tenggara Barat (NTB) saja, namun sudah menyebar ke seluruh pulau di Indonesia.

Dalam wasiat tersebut tertuang cinta-cita besar TGKH. Zainuddin bin Abdul Madjid. Cita-cita tersebut tergambar melalui untaian bait-bait syair yang disusun oleh TGKH. Zainuddin bin Abdul Madjid. Untuk menjaga dan menyebarluaskan organisasi NW. Menurut Muhammad Tohri, dibutuhkan beberapa karakter sebagai penunjang keberlangsungan organisasi tersebut kedepannya. Diantara karakter yang dibutuhkan dalam menjaga ekstensitas dan dalam menyebarluaskan organisasi NW di antaranya adalah karakter ketekunan, kesabaran, pemberani, dan disiplin.

Nilai pendidikan karakter yang sudah disebutkan diatas yang terdapat dalam buku Wasiat Renungan Masa TGKH. Zainuddin bin Abdul Majdid secara tersurat maupun secara tersirat mengajak kepada para murid, alumni, abituren, dan para pecinta organisasi NW untuk menjaga dan mempertahankan supaya organisasi NW tetap eksis seperti organisasi-organisasi lain di Negara Kesatuan Republik Indonesia (NKRI) (Wawancara Kamis, 23 Maret 2017, pukul 15.00 WITA). 
LINGUA, Vol. 16, No. 2, September 2019

p ISSN: 1979 9411; e ISSN: 2442 238X

Http://lingua.soloclcs.org; Email: presslingua@gmail.com

Center of Language and Cultural Studies, Surakarta, Indonesia

Nasip, Abdul; Mahyuni \& Nuriadi. 2019. Nilai Pendidikan, Sosial, Kultural dan Spiritual dalam Wasiat

Renungan Masa, Karya TGKH. Zainuddin Abdul Madjid: Tinjauan Hermeneutika.

Lingua (2019), 16(2): 271-284. Http://doi.org/10.30957/lingua.v16i2.270.

"Sejak berdirinya organisasi NW banyak rintangan yang dialami oleh Maulana As-Syaikh dalam mengembangkan dan menyebarluaskan organisasi NW. Namun beliau tetap tegar dan tidak pantang menyerah. Bagi beliau halangan dan rintangan yang beliau alami, dijadikan sebuah penyemangat dalam berjuang. Pengalaman hidup beliau tuangkan dalam bentuk sebuah buku sastra yang kita kenal selama ini dengan buku Wasiat Renungan Masa. Buku wasiat tersebut, sebagai pedoman dan sebagai pegangan bagi murid, abituren NW dalam berjuang terutama dalam hal hal mempertahankan dan menyebarluaskan organisasi NW. Jadi menurut saya, banyaknya nilai pendidikan karakter yang terdapat dalam wasiat tersebut sebagai upaya Maulana Syaikh menjaga eksentitas organisasi NW setelah beliau wafat (wawancara Kamis, 23 April 2018, pukul 10.00 wita)

Faktor yang memengaruhi dominasi nilai pendidikan karakter dalam Wasiat Renungan Masa TGKH. Zainuddin bin Abdul Madjid adalah menjaga ekstensitas Organisasi NW. Dengan nilai-nilai yang tertanam dalam diri murid, alumni, abituren dan para pecinta ekstensitas Organisasi NW dari masa ke masa akan tetap berkembang.

Nu'man (2016:83) mengatakan bahwa eksistensi NW sebagai organisasi, telah diakui keabsahannya oleh Pemerintah Republik Indonesia berdasarkan Akte Nomor:48 Tanggal 29 Oktober 1956 yang dibuat dan disahkan oleh Notaris Pembantu Hendrik Alexander Malada di Mataram. Dengan akte ini NW belum mempunyai kekuatan hukum untuk bergerak keluar Lombok. Untuk dapat bergerak mengembangkan ke daerah-daerah lain di Indonesia, akte tersebut disempurnakan dan dibuatlah akte untuk yang kedua kalinya, yaitu akte Nomor: 50 Tanggal 25 Juli 1960 dibuat dan disahkan oleh Notaris Pengganti Sie Ik Tiong di Jakarta, penetapan Menteri Kehakiman Nomor:J.A.5/105/5 Tanggal 17 oktober 1960, dan dimuat dalam Tambahan berita Negara Republik Indonesia Nomor: 90 Tanggal 8 Nopember 1960.

Setelah akta kedua ini terbit, maka NW berusaha mengembangkan diri ke berbagai daerah di luar Nusa Tenggara Barat. Maka setelah Tahun 1960 terbentuk Pengurus Organisasi NW seperti di Bali, Nusa Tenggara Timur, Jawa Timur, Daerah Istimewa Yogyakarta, dan Jawa Tengah, DKI Jakarta, Kalimantan, Sulawesi, Riau, dan lain-lain.

Perkembangan NW semakin baik setelah Perguruan Tinggi NW mengeluarkan alumni. Para alumni tersebut setelah kembali ke masyarakat atau ditugaskan atau bekerja ke luar daerah terus berkiprah menata dan mengembangkan organisasi ini secara lebih profesional.

"Seperti yang kita ketahui bersama, dari sekian banyak pengalaman yang pernah Maulana Syaikh alami sejak didirikan organisasi NW pengalaman-pengalaman tersebut beliau tuangkan dalam bentuk wasiat dan di dalam wasiat tersebut terdapat banyak sekali nilai-nilai diantara nilai tersebut adalah nilai pendidikan karakter, sosial, kultural, dan spritual. Hemat saya di antara nilai yang sudah disebutkan di atas nilai pendidikan karakter yang begitu mendominasi dan setelah 
LINGUA, Vol. 16, No. 2, September 2019

p ISSN: 1979 9411; e ISSN: 2442 238X

Http://lingua.soloclcs.org; Email: presslingua@gmail.com

Center of Language and Cultural Studies, Surakarta, Indonesia

Nasip, Abdul; Mahyuni \& Nuriadi. 2019. Nilai Pendidikan, Sosial, Kultural dan Spiritual dalam Wasiat

Renungan Masa, Karya TGKH. Zainuddin Abdul Madjid: Tinjauan Hermeneutika.

Lingua (2019), 16(2): 271-284. Http://doi.org/10.30957/lingua.v16i2.270.

saya amati wasiat tersebut salah satu faktor yang mondominasi nilai pendidikan karakter adalah maulana Syaikh ingin murid, abituren, dan para pecinta NW menjaga dan mengembangkan NW seperti organisasi-organisasi lain di Negara Kesatuan Republik Indonesia (NKRI) (wawancara sabtu, 25 Juni 2018 pukul 15.00 wita).

\subsubsection{Menumbuhkan sikap sami'na waata'na pada seluruh alumni NW}

TGKH. Zainuddin Abdul Madjid sangat menekankan kepada seluruh murid, abituren, dan para pecinta untuk selalu mengembangkan dan memperjuangkan organisasi NW dimana dan kapanpun berada. Penekanan seperti ini sangat penting untuk keberlangsungan dari pada orgasisasi NW. Sehingga dalam Wasiat Renungan Masa banyak kita jumpai bait-bait yang mengarah kepada bagaimana perjuangan dalam rangka menyebar luaskan organisasi NW.

Organisasi NW bisa tetap eksis dari masa kemasa dibutuhkan sebuah karakter dimana karakter tersebut sebagai penopang atau sebagai penyanggah yang begitu kokoh dan tidak bisa tergoyahkan meskipun berbagai macam cobaan dan ujian menimpa kader-kader NW. disinilah karakter ketaatan kepada pimpinan sangat dibutuhkan yang mana dalam organisasi NW kita kenal dengan sami'na waata'na (mendengar dan patuh kepada pimpinan). Kata tersebut sering disampaikan oleh TGKH. Zainuddin bin Abdul Madjid dalam setiap pengajian beliau ketika masih hayat dan sekarang dilanjutkan oleh putri beliau yakni Ummuna $\mathrm{Hj}$. Siti Raihanun Abdul Madjid.

Untuk menumbuhkan karakter ketaatan kepada pimpinan dan kepada seorang guru, TGKH. Zainuddin bin Abdul Madjid menggunakan sebuah karya sastra yang berbentuk syair yang dikenal dengan Wasiat Renungan Masa. Wasiat tersebut tidak hanya dibaca bahkan dinyayikan oleh tim kasidah. TGKH. Zainuddin bin Abdul Madjid sangat faham dengan lingkungan dimana beliau dilahirkan dan bagaimana menanamkan karakter ketaatan kepada pimpinan dan ketaatan kepada seorang guru. Itulah sebabnya, dalam Wasiat Renungan Masa TGKH. Zainuddin bin Abdul Madjid banyak dijumpai bait-bait yang mengarah secara langsung maupun secara tidak langsung yang bisa menumbuhkan pendidikan karakter.

"Seperti yang kita ketahui bersama bahwa Wasiat Renungan Masa adalah pengalaman hidup beliau yang mana dalam wasiat tersebut menurut saya banyak terdapat nilai-nilai terutama yang berkaitan dengan nilai pendidikan karakter, pengaruh dari nilai-nilai yang terdapat dalam Wasiat Renungan Masa tersebut adalah dapat menumbuhkan sikap sami'na waata'na, kenapa demikian karena dengan sikap sami'na waata'na semua murid, abituren dan pencinta NW selalu bersama-sama dalam menumbuhkembangkan organisasi NW. jadi salah satu yang menyebabkan banyaknya nilai pendidikan karakter dalam Wasiat Renungan Masa adalah Maulana Syaikh ingin menumbuhkan sikap sami'na waata'na kepada pimpinan yakni kepada pengurus besar (PB) NW selaku pimpinan tertinggi dalam tubuh organisasi. Jika semua murid, abituren, dan pencinta ta'at kepada pimpinan tentunya organisasi NW akan terus berkembang mengikuti perkembangan zaman 
LINGUA, Vol. 16, No. 2, September 2019

p ISSN: 1979 9411; e ISSN: 2442 238X

Http://lingua.soloclcs.org; Email: presslingua@gmail.com

Center of Language and Cultural Studies, Surakarta, Indonesia

Nasip, Abdul; Mahyuni \& Nuriadi. 2019. Nilai Pendidikan, Sosial, Kultural dan Spiritual dalam Wasiat Renungan Masa, Karya TGKH. Zainuddin Abdul Madjid: Tinjauan Hermeneutika.

Lingua (2019), 16(2): 271-284. Http://doi.org/10.30957/lingua.v16i2.270.

dan tidak mudah tergoyahkan walau berbagai cobaan dan ujian datang silih berganti. (wawancara sabtu, 23 april 2018 pukul 15.00 wita).

Berkaitan dengan pemaparan di atas diketahui bahwa salah satu faktor yang mendominasi nilai pendidikan karakter dalam Wasiat Renungan Masa karya TGKH. Zainuddin bin Abdul Madjid adalah menumbuhkan sikap sami'na waata'na pada seluruh alumni NW. Sikap sami'na waata'na tersebut sangat penting dimiliki oleh semua murid, abituren, dan para pecinta dikarenakan dengan sikap ta'at pada pimpinan akan berdampak sangat besar terhadap keberlangsungan dan kemajuan sebuah organisasi.

\subsubsection{Alat mengobarkan semangat juang para kader $\mathbf{N W}$}

NW merupakan organisasi sosial keagamaan yang lahir di Lombok pada 1953. Organisasi NW ini didirikan oleh TGKH Zainuddin Abdul Majid atau yang lebih dikenal dengan Maulana as-Syaikh, sebagai wadah dakwah Islamiyah dan menjadi payung besar lembaga-lembaga pendidikan madrasah dan perguruan tinggi yang telah didirikan sebelumnya. Latar belakang didirikan Organisasi NW juga karena faktor kepedulian dan tanggung jawab sosial TGKH. Zainuddin atas kondisi masyarakat lokal pada waktu itu yang masih belum begitu maju di berbagai ranah seperti ranah pendidikan, sosial, politik dan keagamaan.

Kehadiran organisasi NW yang membawa misi perubahan sosial keagamaan mendapat tantangan berat dari sebagian tokoh masyarakat, karena mereka menilai TGKH. Zainuddin telah membawa paham keagamaan yang baru dan diklaim sebagai bagian dari gerakan Wahabisme. Langkah TGKH. Zainuddin bin Abdul Madjid yang mengubah sistem pesantren menjadi madrasah pada tahun 1937 dengan menggunakan kurikulum modern telah melahirkan kecemburuan dan kecurigaan dari tokoh agama yang lain. Namun terlepas dari itu, organisasi NW dalam perjalanannya terus eksis dan menunjukkan perkembangan yang cukup pesat di semua bidang baik di bidang pendidikan, dakwah dan sosial. Sejak tahun 1980-an hingga sekarang organisasi NW menjelma menjadi organisasi kemasyarakatan dengan massa terbesar di Lombok.

Sebagai kelompok mayoritas, organisasi NW mempunyai kekuatan dan esksistensi sangat diperhitungkan khususnya pasca reformasi 1998. Keberhasilan cucu beliau yaitu TGKH. Muhammad Zainul Majdi atau yang lebih dikenal dengan Tuan Guru Bajang sebagai Gubernur Nusa Tenggara Barat dan Samsul Lutfi sebagai Wakil Bupati Lombok Timur pada Pilkada 2008 menjadi bukti bahwa organisasi NW semakin kuat dan memainkan peran penting di tingkat lokal.

Prestasi tersebut tentunya berkaitan dengan karakter-karakter yang dibentuk dan ditanamkan oleh TGKH. Zainuddin bin Abdul Madjid yang mana karakter tersebut, beliau tuangkan dalam wasiatnya. Sehingga dimanapun dan kapanpun berada, kader Nahdlatul Wathan siap berjuang dengan semangat yang tinggi, pantang menyerah, dan penuh pengorbanan. 
LINGUA, Vol. 16, No. 2, September 2019

p ISSN: 1979 9411; e ISSN: 2442 238X

Http://lingua.soloclcs.org; Email: presslingua@gmail.com

Center of Language and Cultural Studies, Surakarta, Indonesia

Nasip, Abdul; Mahyuni \& Nuriadi. 2019. Nilai Pendidikan, Sosial, Kultural dan Spiritual dalam Wasiat Renungan Masa, Karya TGKH. Zainuddin Abdul Madjid: Tinjauan Hermeneutika.

Lingua (2019), 16(2): 271-284. Http://doi.org/10.30957/lingua.v16i2.270.

"Dalam Wasiat Renungan Masa bagaimana Maulana Syaikh memberikan motivasi, spirit dan nasehat-nasehat yang sangat menyentuh dan apabila kita hayati makna bait demi bait dari wasiat tersebut, kita akan menemukan diri kita akan merasa terbang, bergairah, tidak mudah menyerah dalam hal perjuangan. Hal tersebut tidak hanya saya yang merasakan akan tetapi teman-teman yang lain sesama alumni juga mengatakan demikian. Setelah mereka membaca wasiat semangat perjuangan mereka membara dan menyala tidak bisa padam. Dengan ini bisa kita simpulkan bahwa Maulana Syaikh menanamkan karakter pantang menyerah, bersungguh-sungguh dalam berjuang sengaja beliau tanamkan melalui wasiat beliau. Jadi menurut saya salah satu faktor yang menyebabkan dominasi nilai pendidikan karakter dalam Wasiat Renungan Masa adalah Maulana Syaikh mengobarkan semangat juang bagi murid, abituren, dan para pencinta NW untuk selalu berjuang dan istiqomah (wawancara rabu, 25 Maret 2017 pukul 15.00 wita)

Berdasarkan hasil wawancara di atas, menguatkan bahwasanya dominasi nilai pendidikan karakter dalam Wasiat Renungan Masa yang berbentuk bait syair oleh TGKH. Zainuddin bin Abdul Madjid, dikarenakan beliau ingin menanamkan semangat juang kepada seluruh murid, abitren, dan para pecinta NW. Dengan semangat yang pantang menyerah inilah organisasi NW sampai saat ini tumbuh dan terus berkembang keberbagai daerah se-Indonesia.

\subsubsection{Pewaris Para Nabi}

TGKH. Zainuddin bin Abdul Madjid mengemban amanah yang begitu besar atas perubahan karakter ummat terutama masyarakat Lombok yang mana ketika itu sangat terbelakang tidak hanya dari segi pendidikan namun dari segi akhlak. Itulah sebabnya sebagai ulama' pewaris para nabi beliau merasa terpanggil sebagai penggagas sebuah pendidikan karakter sehingga dalam karya-karya beliau selalu menampilakan sebuah karakter kebaikan, rasa ingin tahu, jujur, amanah, tawakkal dan tidak mudah menyerah. Dengan demikian masyarakat lombok yang dulunya terbelakang kini menjadi masyarakat yang maju.

"Saya melihat banyaknya nilai pendidikan karakter dalam Wasiat Renungan Masa disebabkan oleh keulamaan beliau. Kenapa saya mengatakan demikian dikarenakan TGKH. Zainuddin bin abdul Madjid adalah seorang ulama besar, tentu seorang ulama' berkewajiban mendidik, dan merubah karakter masyarakatnya kearah yang lebih baik. Dengan demikian banyaknya nilai pendidikan karakter yang mendominasi Wasiat Renugan Masa adalah disebabkan karena TGKH. Zainuddin bin Abdul Madjid adalah ulama' pewaris para Nabi sebagai seorang pewaris tentunya akan mengikuti jejak dari pada yang mewarisi yakni Nabi Muhammad SAW. Rasullah SAW diturunkan kemuka bumi ini untuk merubah akhlak manusia. (Wawancara, senin 25 April 2017 pukul 15.00 wita). 
LINGUA, Vol. 16, No. 2, September 2019

p ISSN: 1979 9411; e ISSN: 2442 238X

Http://lingua.soloclcs.org; Email: presslingua@gmail.com

Center of Language and Cultural Studies, Surakarta, Indonesia

Nasip, Abdul; Mahyuni \& Nuriadi. 2019. Nilai Pendidikan, Sosial, Kultural dan Spiritual dalam Wasiat Renungan Masa, Karya TGKH. Zainuddin Abdul Madjid: Tinjauan Hermeneutika.

Lingua (2019), 16(2): 271-284. Http://doi.org/10.30957/lingua.v16i2.270.

Berdasarkan wasil wawancara di atas, dapat kita simpulkan bahwa diantara faktor yang mendominasi nilai pendidikan karakter dalam wasiat renungan masa yaitu mengenai tugas dari pada Maulana as-Syaikh sebagai pewaris para nabi. Pewarsi para nabi yang dimaksud disini adalah ulama' dan seperti yang kita ketahui bersama. Bahwasanya Maulana as-Syaikh adalah dikenal sebagai ulama' besar tidak hanya di Indonesia tapi juga diberbagai penjuru dunia. Dengan faktor keulama'an beliau tentunya beliau mempunyai tanggung jawab besar untuk merubah karakter ummat, yang mana karakter kejujuran, amanah, ketaatan, disiplin dan sabar saat ini sudah tidak begitu diperhatikan oleh seseorang. Terlebih lagi saat ini kita hidup dizaman yang penuh dengan fitnah yang tidak mudah seseorang melepaskan diri apalagi menghindar dari fitnah tersebut.

\subsubsection{Menumbuhkan Sikap Fanatisme kepada NW}

Dalam menjaga dan mengembangkan organisasi Nahdlatul Wathan TGKH. Zainuddin bin Abdul Madjid menanamkan sebuah sikap atau karakter kepada murid, alumni, abituren dan semua pecinta yang dikenal dengan sikap fanatisme, sikap fanatisme ini bukan maksudnya fanatisme buta dan tidak mau menerima perbedaan yang biasanya terjadi. Fanatisme disini adalah sebuah sikap dan tindakan sebagai pembelaan atas apa yang menjadi pandangan dari pada TGKH. Zainuddin bin Abdul Madjid tentang sebuah hukum dan pandangan beliau dalam menyikapi persoalan yang terjadi dalam organisasi Nahdlatul Wathan atau fenomena sosial dalam kehidupan.Untuk menumbuhkan sikap fanatisme tersebut, dibutuhkan sebuah karakter yang harus ditanamkam dan hal ini beliau lakukan melalui pengajian-pengajian dan melalui karangan beliau. Hal tersebut bisa kita lihat dalam buku Wasiat Renungan Masa dan buku karangan beliau yang lain.

"Nahdlatul Wathan adalah organisasi besar yang didirikan oleh Maulana Syaikh, sebagai organisasi besar tentunya memiliki banyak cabang-cabang yang tersebar keseluruh pulai di Indonesia, tidak hanya itu Maulana Syaikh juga mempunyai ribuan murid dan alumni yang tersebar keberbagai pelosok negeri. Menurut saya ribuan murid, dan alumni yang banyak tersebut harus mempunyai sikap fanatisme kepada guru maupun kepada almamaternya. Hal tersebut sangat penting. Kenapa demikian, dikarenakan dengan sikap fanatisme kepada almamater atau guru inilah, seseorang akan tetap taat dan setia kepada guru dan kepada almamaternya. (wawancara sabtu, 25 Juni 2018 pukul 15.00 wita).

Berdasarkan hasil wawancara di atas, menguatkan kepada kita bahwasanya yang menjadi dasar dari banyaknya nilai pendidikan karakter dalam Wasiat Renungan Masa karya TGKH. Zainuddin bin Abdul Madjid adalah untuk menumbuhkan sikap fanatisme murid, abituren, dan para pecinta organisasi NW. Fanatisme disini sebagai wujud dari pengamalan ilmu yang didapatkan selama menempuh pendidikan di lembaga NW. 
LINGUA, Vol. 16, No. 2, September 2019

p ISSN: 1979 9411; e ISSN: 2442 238X

Http://lingua.soloclcs.org; Email: presslingua@gmail.com

Center of Language and Cultural Studies, Surakarta, Indonesia

Nasip, Abdul; Mahyuni \& Nuriadi. 2019. Nilai Pendidikan, Sosial, Kultural dan Spiritual dalam Wasiat Renungan Masa, Karya TGKH. Zainuddin Abdul Madjid: Tinjauan Hermeneutika.

Lingua (2019), 16(2): 271-284. Http://doi.org/10.30957/lingua.v16i2.270.

\section{SIMPULAN}

Simpulan penelitian ini mengacu pada tiga aspek perumusan masalah terkait Wasiat Renungan Masa. Wasiat Renungan Masa bukan tercipta semata-mata sebagai alat komunikasi dialogis atau referensi bacaan. Namun demikian TGKH. Zainuddin Abdul Madjid sebagai pengarangnya menyusun dan mengabadikan pesan-pesan tersebut sebagai kitab panduan dan koreksi bagi warga NW secara khusus dan warga Indonesia secara umum dalam menjalani kehidupanya. Selain itu, TGKH. Zainuddin Abdul Madjid menggunakan sebuah karya sastra yang berbentuk syair untuk menyampaikan pesan kepada anak keturunan dan murid-muridnya sebagai bekal dalam berjuang mempertahankan eksistensi organisasi NW dengan gaya bahasa yang beragam, santun, mudah, dan sangat tegas.

Dalam penggunaan diksi dalam syair WRM tersebut. TGKH. Zainuddin Abdul Madjid menggunakan tiga sumber diksi dari tiga bahasa yang berbeda, yaitu bahasa Indonesia, Arab, dan Sasak. Meskipun secara mayoritas bahasa utama yang digunakan dalam syair WRM tersebut adalah bahasa Indonesia. Percampuran diksi dari tiga sumber bahasa yang berbeda memperlihatkan kreatifitas pengarangnya selain itu diksi yang dugunakan dalam Syair WRM mengandung arti konotatif.

\section{DAFTAR PUSTAKA}

Aprilia, Sinta. 2011. Aplikasi Nilai Kultural-Spiritual dalam Kehidupan Masyarakat. Surabaya: Pustaka Airlangga.

Arikunto, Suharsimi. 2013. Prosedur Penelitian: Suatu Pendekatan Praktik. Jakarta: Rineka Cipta.

Emzir. 2010. Metodologi Penelitian Pendidikan: Kuantitatif dan Kualitatif. Jakarta: Raja Grafindo Persada.

Endraswara, Suwardi. 2015. Metodologi Penelitian Sastra: Konsep, Langkah, dan Penerapan. Jogjakarta: CAPS.

Hadi, Sofian. 2003. Kajian Teoretik Hermeneutika Simbolik. Surabaya: Pustaka Airlangga.

Mahsun. 2011. Metode Penelitian Bahasa: Tahapan, Strategi, Metode, dan Tekniknya (edisi revisi 2011). Jakarta: Rajawali Pers.

Moleong, Lexy J. 1997. Metodologi Penelitian Kualitatif. Bandung: Remaja Rosdakarya.

Muhammad. 2014. Metode Penelitian Bahasa. Jakarta: Gramedia Pustaka Utama.

Palmer, Richard. 2003. Hermeneutics, Interpretation Theory in Schleirmacher, Dilthey, Heidegger and Gadamer. Evanstron: Northwestern University Press.

Pradopo, Rachmat Djoko. 2013. Beberapa Teori Sastra, Metode Kritik, dan Penerapannya. Yogyakarta: Hanindita Graha Widya.

Ratna, Nyoman Kutha. 2011. Teori, Metode, dan Tekhnik Penelitian Sastra. Yogyakarta: Pustaka Pelajar.

Ricoeur, Paul. 2014. Teori Interpretasi: Membelah Makna dalam Anatomi Teks. Jogjakarta: IRCiSoD.

Silalahi, Uber. 2012. Metode Penelitian Sosial. Bandung: Refika Aditama. 
LINGUA, Vol. 16, No. 2, September 2019

p ISSN: 1979 9411; e ISSN: 2442 238X

Http://lingua.soloclcs.org; Email: presslingua@gmail.com

Center of Language and Cultural Studies, Surakarta, Indonesia

Nasip, Abdul; Mahyuni \& Nuriadi. 2019. Nilai Pendidikan, Sosial, Kultural dan Spiritual dalam Wasiat Renungan Masa, Karya TGKH. Zainuddin Abdul Madjid: Tinjauan Hermeneutika.

Lingua (2019), 16(2): 271-284. Http://doi.org/10.30957/lingua.v16i2.270.

Sriyanto, Abdullah. 2011. Konsep Nilai dalam Masyarakat Nasional. Jogjakarta: Arwana Press.

Sugiyono. 2016. Metode Penelitian Pendidikan. Bandung: Alfabeta.

Thohri, Muhammad. 2015. Menyusuri Keagungan Cinta Maulana. Mataram: Sanabil Nahdlatul Wathan.

Toha, Suryadarma. 2011. Nilai dan Norma. Jakarta: Rodajaya Publisher. 
LINGUA, Vol. 16, No. 2, September 2019

p ISSN: 1979 9411; e ISSN: 2442 238X

Http://lingua.soloclcs.org; Email: presslingua@gmail.com

Center of Language and Cultural Studies, Surakarta, Indonesia

Nasip, Abdul; Mahyuni \& Nuriadi. 2019. Nilai Pendidikan, Sosial, Kultural dan Spiritual dalam Wasiat Renungan Masa, Karya TGKH. Zainuddin Abdul Madjid: Tinjauan Hermeneutika.

Lingua (2019), 16(2): 271-284. Http://doi.org/10.30957/lingua.v16i2.270. 